\title{
RECOVERY ENGINEERING OF EX-ILLEGAL SAND AND STONE MINING ON THE SLOPES OF MOUNT MERAPI
}

\author{
Jaka Purwanta ${ }^{1}$, Suharwanto ${ }^{2}$, and Trismi Ristyowati ${ }^{3}$ \\ ${ }^{1}$ Department of Environmental Engineering, Universitas Pembangunan Nasional "Veteran" \\ Yogyakarta, Jl. Pajajaran (SWK 104), Condongcatur, Depok, Sleman, Yogyakarta, 55283, \\ Indonesia \\ ${ }^{2}$ Department of Environmental Engineering, Universitas Pembangunan Nasional "Veteran" \\ Yogyakarta, Jl. Pajajaran (SWK 104), Condongcatur, Depok, Sleman, Yogyakarta, 55283, \\ Indonesia \\ ${ }^{3}$ Department of Industrial Engineering, Universitas Pembangunan Nasional "Veteran" \\ Yogyakarta, Jl. Babarsari 2 Tambakbayan, Condongcatur, Depok, Sleman, Yogyakarta, \\ 55283 , Indonesia
}

\begin{abstract}
This study aims to study the environmental damage caused by illegal/illegal mining of sand and stones on the slopes of Mount Merapi and the impact of the land restoration plan and its management efforts. The location of this research is in Sleman Regency, DIY, especially in Karangkendal Hamlet. Balong Hamlet, Umbulharjo Village, Cangkringan District. This area has attractive ecotourism or ecotourism potential which is supported by the majority of land use for agricultural land, aspects of nature conservation, aspects of socio-cultural economic empowerment of local communities, as well as aspects of learning and education. However, this location is also one of the locations for the deposition of sandstone and cold lava when Mount Merapi erupted. The material is a construction material so that under normal conditions, there is a process of illegal mining of sand and stone at that location by the community around the location. Problems arise due to mining activities without prior technical planning resulting in environmental damage at the location, both on the contours of the mined land into steep cliffs that are prone to landslides and disturbances to the vegetation and fauna. CV. Rubi Khan Daiman as a third party who got a job from the Sleman Regency Government to carry out land recovery mitigation activities, then collaborated with researchers to conduct the study. Based on the research results, the planned land restoration activities will not only have positive impacts but also negative impacts on the surrounding environment.
\end{abstract}

Keywords: Agricultural land, environmental damage, eruption, illegal mining, mitigation 
Cite this Article: Jaka Purwanta, Suharwanto, and Trismi Ristyowati. Recovery Engineering of Ex-Illegal Sand and Stone Mining on the Slopes of Mount Merapi. International Journal of Civil Engineering and Technology (IJCIET). 12(8), 2021. pp. 66-72.

https://iaeme.com/Home/issue/IJCIET?Volume $=12 \&$ Issue $=8$

\section{INTRODUCTION}

Ande One of the villages in the Sleman Regency area that has the potential for ecotourism or ecotourism is Umbulharjo Village and one of the locations in its area that is the object of this research is Karangkendal Hamlet Padukuhan Balong. Ecotourism or ecotourism is one of the environmentally friendly tourism activities by prioritizing aspects of nature conservation, aspects of socio-cultural economic empowerment of local communities as well as aspects of learning and education. This tourism potential is supported by the majority of the area being used as agricultural land. However, it turns out that Umbulharjo Village is also one of the villages in Cangkringan District which is an area of sandstone and cold lava deposition from the eruption of Mount Merapi so that Cangkringan District is an area affected after the eruption of Mount Merapi.

Based on the Law of the Republic of Indonesia Number 32 of 2009 concerning Environmental Protection and Management, all activities that will have an impact on the environment, both positive and negative, must be managed. It aims to minimize negative impacts and maximize positive impacts. This was then followed up with the existence of the Government of Indonesia Regulation Number 27 of 2012 concerning Environmental Permits. The latest regulation is Law of the Republic of Indonesia Number 11 of 2020 concerning Work Areas and its derivative regulations, namely Government Regulation of the Republic of Indonesia Number 22 of 2021 concerning the Implementation of Environmental Protection and Management (P3LH).

CV. Rubi Khan Daiman as the initiator/business actor who will carry out mitigation of land damage by means of land restoration activities, previously had to obtain an Environmental Permit from the Sleman Regency Environmental Service. Based on the survey results, it was found that illegal sand and stone mining (sirtu) had been carried out because there was no technical planning and no Environmental Permit. This will have a negative impact on the surrounding environment such as the potential for landslides, damage to agricultural land, and land that cannot be used for the long term (unproductive land). An activity at both the construction and operational stages will have an impact on the lives of the people around the activity location, such as community income and public health. (Fityatur, 2015)[2].

Land restoration is carried out by means of land that will be arranged so as to form a terrace. For this reason, sand and stones must be removed from the activity site. During the process of removing sand and stones from the activity site, it is estimated that there will be several negative impacts such as a decrease in air quality caused by dust scattering from sand transported by trucks and dust from roads passed by trucks. Likewise, there will be an increase in noise from the sound of trucks passing by on the haul road. The dust is then spread to settlements around the location and the dust particles will be inhaled by the people living around the location. Exposure to this dust can interfere with the respiratory tract of people outside the home. (Thaib et al, 2014)[5]. According to Nurbiyantara (2010)[4], Exposure to inhaled dust particles in the respiratory tract will cause various lung function disorders. Fine dust particles will accumulate in the respiratory tract according to the chemical, physical, and biological properties of the dust. According to Ather Sultan (2004)[7] that fine dust can cause impaired lung function, chronic obstructive pulmonary disease, restrictive lung disease, pneumoconiosis and carcinoma of the lung, stomach and large intestine. According to Naqpure (2014)[3] dust is termed as TSP which 
is defined as PM (Particulate Material) with an aerodynamic diameter of not more than $30 \mathrm{~m}$. According to Ather Sultan (2004)[7] that fine dust can cause impaired lung function, chronic obstructive pulmonary disease, restrictive lung disease, pneumoconiosis and carcinoma of the lung, stomach and large intestine. According to Naqpure (2014)[3] dust is termed as TSP which is defined as PM (Particulate Material) with an aerodynamic diameter of not more than $30 \mathrm{~m}$. According to Ather Sultan (2004)[7] that fine dust can cause impaired lung function, chronic obstructive pulmonary disease, restrictive lung disease, pneumoconiosis and carcinoma of the lung, stomach and large intestine. According to Naqpure (2014)[3] dust is termed as TSP which is defined as PM (Particulate Material) with an aerodynamic diameter of not more than $30 \mathrm{~m}$.

According to Dimitriou and Christidou (2011)[1], air pollution is one of the most important environmental problems that contribute to the effects of high temperatures on public health, animal life, natural ecosystems, and the man-made environment. Air pollution is also responsible for climate change, the greenhouse effect, acid rain, and others.

According to Suhariyono and Wiyono (2003)[8], the main sources of dust in the atmosphere are soil, seawater jets, bush fires, household burning, motor vehicles, industrial processes, and organic dust from plant material. The dust that is scattered on the road passed by the sand and stone hauling trucks is fine dust. Dusts smaller than $10 \mathrm{~m}$ have a greater ability to penetrate into the lungs. The hairs in the nose can filter dust larger than $10 \mathrm{~m}$, while particles smaller than this size exhibit Brownian motion and do not hit the side walls but can enter the lung vesicles. Particles smaller than $2.5 \mathrm{~m}(\mathrm{PM} 2,5)$ cannot be filtered in the upper respiratory system and stick to the lung bubbles so that it can reduce gas exchange. PM10 particulate matter includes particles with aerodynamic diameters smaller than $10 \mathrm{~m}$. These particles, which cause many adverse health effects, can reach the thorax or the lower respiratory tract. Next will be attacked by ARI (Acute Respiratory Infection). As a tertiary impact, people's income will decrease because people who are affected by ARI cannot work so they have no income. On a larger scale, a decrease in people's income will reduce the level of the community's economy. PM10 particulate matter includes particles with aerodynamic diameters smaller than $10 \mathrm{~m}$. These particles, which cause many adverse health effects, can reach the thorax or the lower respiratory tract. Next will be attacked by ARI (Acute Respiratory Infection). As a tertiary impact, people's income will decrease because people who are affected by ARI cannot work so they have no income. On a larger scale, a decrease in people's income will reduce the level of the community's economy. PM10 particulate matter includes particles with aerodynamic diameters smaller than $10 \mathrm{~m}$. These particles, which cause many adverse health effects, can reach the thorax or the lower respiratory tract. Next will be attacked by ARI (Acute Respiratory Infection). As a tertiary impact, people's income will decrease because people who are affected by ARI cannot work so they have no income. On a larger scale, a decrease in people's income will reduce the level of the community's economy. As a tertiary impact, people's income will decrease because people who are affected by ARI cannot work so they have no income. On a larger scale, a decrease in people's income will reduce the level of the community's economy. As a tertiary impact, people's income will decrease because people who are affected by ARI cannot work so they have no income. On a larger scale, a decrease in people's income will reduce the level of the community's economy.

Meanwhile, according to Saraswati (2000)[6], land management activities and coffee plantation operations will trigger urbanization and threaten the environment through air, soil, and water pollution it causes. 


\section{MATERIALS \& EXPERIMENTAL PROCEDURES}

\subsection{Research Sites}

This research is located in Karangkendal Hamlet, Balong Padukuhan, Umbulharjo Village, Cangkringan District, Sleman Regency, Special Region of Yogyakarta.

\subsection{Materials and Equipment}

This study uses equipment and materials in the form of a laptop. camera, stationery, and literature/secondary data.

\subsection{Method}

\subsubsection{Dentify the legal basis for legality;}

\subsubsection{Conduct site observations;}

\subsubsection{Perform data analysis;}

\subsubsection{Provide impact management recommendations.}

\section{RESULTS AND DISCUSSION}

\subsection{Identifying the Legal Basis of Legality}

Researchers searched various literatures and reference sources to identify regulations that could be the legal basis for the legality of the environmental damage mitigation plan. As the basis for the mitigation plan for environmental damage, namely the Decree of the Sleman Regent Number 76.20/Kep.KDH/A/2019 dated 25 November 2019 concerning the Restoration of Agricultural Land on the Slopes of Merapi after the Merapi Volcano Eruption and the Decree of the Head of the Agriculture, Food and Fisheries Service of Sleman Regency Number 525 /1818 April 24, 2020 concerning Recommendations for Restoration of Agricultural Land.

\subsection{Doing Location Observations}

After the researchers made observations to the research location, the data obtained from the environmental baseline conditions of the research location were as follows.

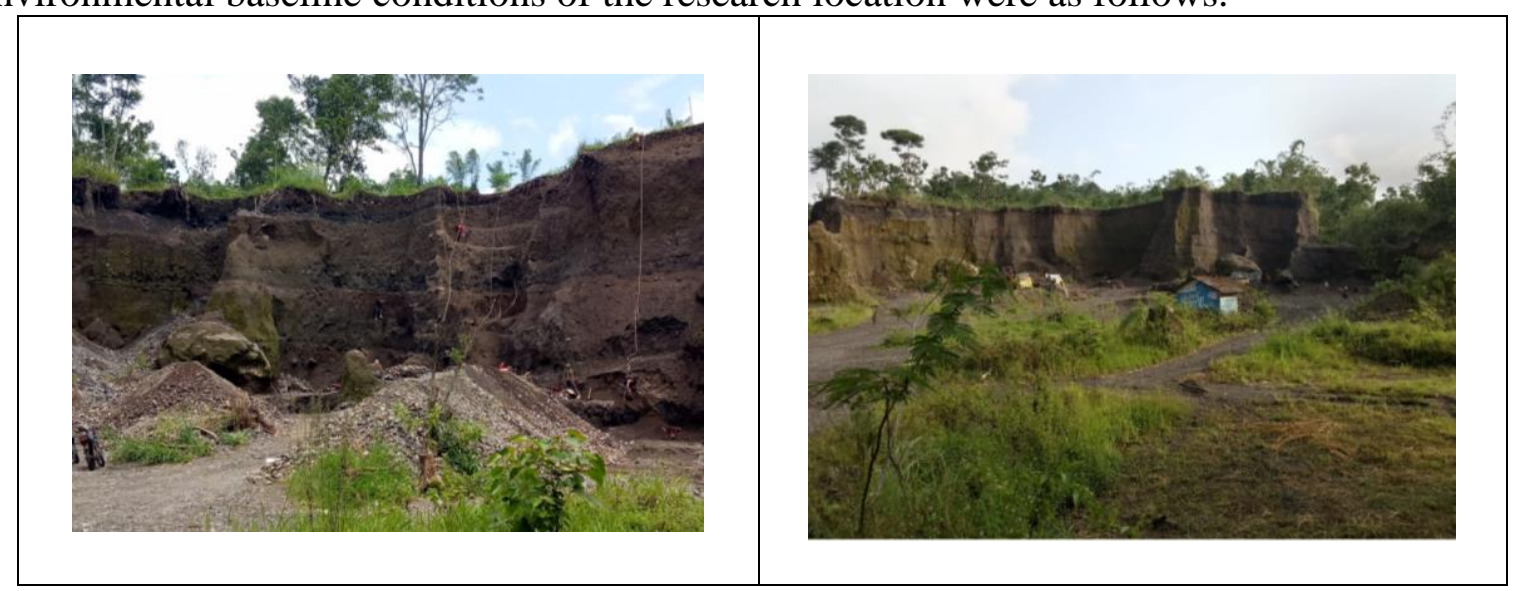

Figure 1. The condition of the living environment of the research location

(Source: primary data, 2021)

In the picture above, it can be seen that there has been a decrease in environmental quality. The existence of sand dunes and rocks that are mined without regard to the safety risks of workers and cause steep cliffs that are prone to landslides. Likewise, the surrounding vegetation will be disturbed by changes in environmental conditions. 


\subsection{Data Analysis}

Researchers conducted an analysis of the environmental baseline conditions at the research site due to illegal sand and stone mining without being preceded by technical planning and Environmental Permits, namely as follows:

- Prior to mining, land clearing of the mining site is carried out so as not to leave large plants. This results in a disturbance impact on the flora;

- The secondary impact of the impact of disturbance on flora is that it will cause disturbance to fauna. Fauna at the research site and its surroundings will leave the site or die due to the impact of land clearing activities;

- Mining of sand and rock without performing detailed geotechnical calculations will result in the dune and rock being mined becoming steep and prone to landslides. This is very dangerous because it can hoard the workers under it. In this condition, there is a disturbance impact on Occupational Safety and Health (K3);

- A lot of flora is lost from the activity site, causing disturbance to the flora;

- Many fauna have left or died because the trees where they live have been cut down, causing disturbances to the fauna;

- The existence of equipment and material mobilization activities will cause dust and noise, resulting in a decrease in air quality and an increase in noise.

- In addition, the mobilization activities will cause disruption to traffic and damage to roads;

- The existence of sand and stone mining activities should be able to grow the impact of business opportunities in the community such as the emergence of food stalls, grocery stores, and others to meet the needs of workers;

- The growing impact of business opportunities on the community will have a follow-up impact, namely the emergence of the impact of increasing community income;

- The existence of sand and stone mining also causes public unrest due to changes in land use and workers who carry out mining are not necessarily residents around the mining site.

\subsection{Providing Impact Management Recommendations}

After analyzing the data on environmental damage that occurred, then the researchers gave recommendations to $\mathrm{CV}$. Rubi Khan Daiman as the executor of environmental damage mitigation and land recovery plans so that the stages and activities to be carried out in the land recovery plan should be detailed so that it is easier to provide recommendations for impacts that should be managed. The activities and their impacts are as follows:

Table 1 Stages, activities, and impacts that need to be managed

\begin{tabular}{|c|c|c|c|}
\hline No & Activity step & Name of activity & Managed Impact Name \\
\hline \multirow[t]{2}{*}{ A. } & \multirow[t]{2}{*}{ Preconstruction } & $\begin{array}{l}\text { Socialization of activity } \\
\text { plans }\end{array}$ & The emergence of public unrest \\
\hline & & Land use & The emergence of public unrest \\
\hline \multirow[t]{6}{*}{ B. } & \multirow[t]{6}{*}{ Construction } & \multirow{2}{*}{$\begin{array}{l}\text { Construction workforce } \\
\text { recruitment }\end{array}$} & Increased job opportunities \\
\hline & & & Public unrest \\
\hline & & \multirow[t]{2}{*}{ Activities at base camp } & Liquid waste generation \\
\hline & & & Solid waste generation \\
\hline & & \multirow{2}{*}{$\begin{array}{l}\text { Mobilization of equipment } \\
\text { and materials }\end{array}$} & B3 waste generation \\
\hline & & & Decreasing groundwater quality \\
\hline
\end{tabular}


Recovery Engineering of Ex-Illegal Sand and Stone Mining on the Slopes of Mount Merapi

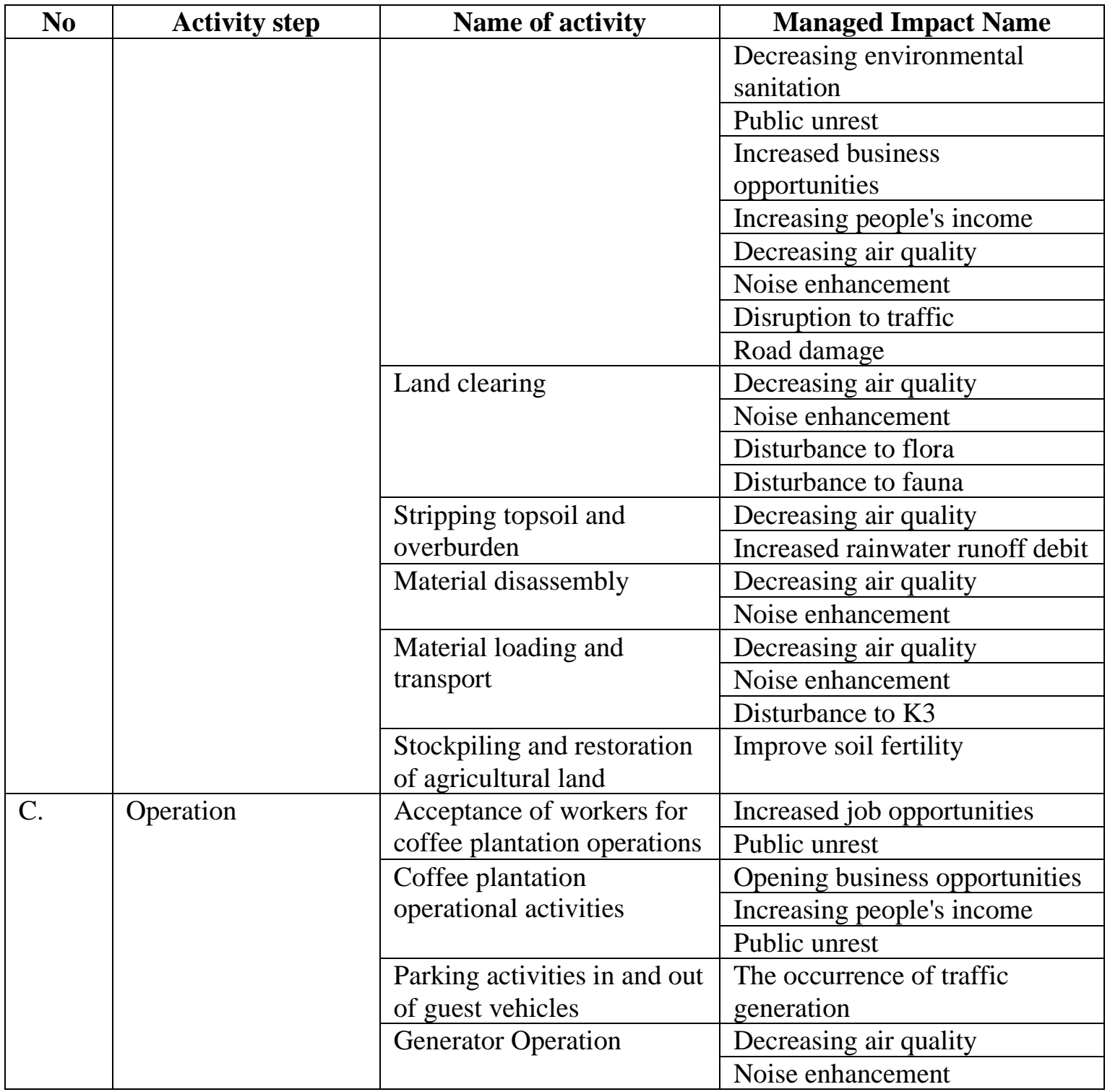

Source: data processing, 2021

\section{SUMMARY}

CV. Rubi Khan Daiman as the party that will carry out mitigation of environmental damage in the form of land restoration activities, already has a legal basis and has made observations in the field. Based on data analysis, it can be concluded that environmental damage has occurred and provides recommendations to $\mathrm{CV}$. Rubi Khan Daiman to manage the impacts, both positive and negative impacts, as well as monitoring the management carried out so that positive impacts can be maximized and negative impacts can be minimized.

\section{ACKNOWLEDGMENTS}

The authors would like to thank the Institute for Research and Community Service, Universitas Pembangunan Nasional Veteran Yogyakarta, Indonesia, which has provided financial support for this research. Thanks are also conveyed to CV. Rubi Khan Daiman who has given permission to be the research site. 


\section{REFERENCES}

[1] Dimitriou, A. and Christidou, V., 2011, "Causes and Consequences of Mix Pollution and Environmental Injustice as Critical Issues for Sciences and Environmental Education”, p.218, The Impact of Air Pollution on Health, Economy, Environment, and Agricultural Sources, In Tech.

[2] Fityatur, R., 2015, "Dampak Sosial-Ekonomi Pabrik Semen Puger Di Kecamatan Puger Kabupaten Jember", Jember.

[3] Naqpure, A.S., et al, 2014, "Human Health Risks in National Caiptal Territory Of Delhi due to Air Pollution", p.373, Atmospheric Pollution Research, India.

[4] Nurbiyantoro, S., 2010, "Pengaruh Polusi Udara Terhadap Fungsi Paru-Paru Polisi Lalu Lintas Di Surakarta", hal.44-45, UNS, Surakarta.

[5] Thaib, Y.P. dkk, 2014, Hubungan Antara Paparan Debu Dengan Kejadian Gangguan Saluran Pernafasan Pada Masyarakat Kelurahan Kairagi Satu Lingkungan 3 Kota Manado, Universitas Sam Ratulangi, Manado.

[6] Saraswati, 2000, "Penerapan RKL dan RPL Pada Industri Semen (Studi Kasus PT. Semen Gresik (Persero) Tbk Pabrik Tuban I, II, III, Jawa Timur", Tuban.

[7] Sultan, A., 2004, "Health Hazards of Cement Dust", Saudia Medical Journal 25 (9):1153-9.

[8] Suhariyono, G. dan Wiyono, M., 2003, "Distribusi Diameter Partikel Debu $\mathrm{PM}_{10}$ dan $\mathrm{PM}_{2,5}$ dalam Udara Sekitar Kawasan Pabrik semen Citeureup, Bogor", Prosiding Seminar Aspek Keselamatan Radiasi dan Lingkungan Pada Industri Non Nuklir 18 maret 2003, Jakarta 